https://doi.org/10.11646/zootaxa.4387.3.10

http://zoobank.org/urn:lsid:zoobank.org:pub:019E67D5-4F5C-461D-B5CD-F06224DE709C

\title{
A new species of Physalaemus (Anura, Leptodactylidae) from the Atlantic Forest of Misiones, northeastern Argentina
}

\author{
DARIO E. CARDOZO ${ }^{1,3}$ \& MARTIN O. PEREYRA ${ }^{2}$ \\ ${ }^{l}$ Laboratorio de Genética Evolutiva, Instituto de Biología Subtropical (CONICET-UNaM), CPA N3300LQF. Posadas, Misiones, \\ Argentina. \\ ${ }^{2}$ División Herpetología, Museo Argentino de Ciencias Naturales “Bernardino Rivadavia”-CONICET, C1405DJR, Buenos Aires, \\ Argentina. \\ ${ }^{3}$ Corresponding author. E-mail: darcardz@gmail.com
}

\begin{abstract}
A new species of Physalaemus from Misiones province, Argentina, in the Atlantic forest domain is described. The new species is a member of the $P$. gracilis group, based on its phylogenetic position and the occurrence of a putative morphological synapomorphy (occurrence of an unpigmented median stripe on throat, chest, and/or abdomen). Physalaemus sp. nov. is characterized by a long advertisement call composed of non-pulsed notes with slightly descendant modulation, large size (mean SVL = $32.0 \mathrm{~mm}$ males, $34.0 \mathrm{~mm}$ females), slender body aspect, head longer than wide, supratympanic fold developed, an unpigmented median stripe on venter, medium sized inguinal glands, tarsal tubercle present, and supernumerary tubercles on hands and feet, which are character states that combined distinguish the new species from all the members of the genus. In this study, we provide its formal description based on external morphology, advertisement call, and 16S genetic distance. In addition, the distribution ranges for the new species and $P$. gracilis are revisited, the advertisement call of $P$. gracilis is redescribed, and a discussion about the available names which could be applicable to the new species is provided.
\end{abstract}

Key words: Physalaemus sp. nov.; Physalaemus gracilis; External morphology; 16S rRNA sequences, Advertisement call

\section{Introduction}

The neotropical frog genus Physalaemus currently comprises 47 described species distributed in northern and central Argentina, eastern Bolivia, Brazil, llanos of southeastern Colombia, the Guianas, Paraguay, Uruguay, and lowlands of southern Venezuela (Lourenço et al., 2015; Frost, 2017). Attempts to delimit the species group of Physalaemus range from phenetic inferences (i.e., Lynch, 1970; Nascimento et al., 2005) to molecular phylogenetic analyses (Ron et al., 2005, 2006; Lourenço et al., 2015). The most recent and inclusive phylogenetic analysis (Lourenço et al., 2015) recovered Physalaemus (including Eupemphix) as a monophyletic group, composed by two major clades: the $P$. signifer clade, including $P$. nattereri and the species previously assigned to $P$. deimaticus and $P$. signifer groups by Nascimento et al. (2005), and the $P$. cuvieri clade including the remaining species of the genus. In this later clade, a group containing the five species assigned to the $P$. gracilis group by Nascimento et al. (2005) plus Physalaemus sp. from Parque Provincial Moconá (Misiones, Argentina) was recovered in all the analyses. This undescribed species, sister of $P$. jordanensis $+P$. barrioi (Lourenço et al., 2015) was historically misidentified as P. gracilis (e.g., Berg, 1896; Barrio, 1965; Gallardo, 1966; Cei, 1980; Gallardo \& Varela, 1992). In this work, we provide a formal description of this species based on external morphology, advertisement call, and genetic distance of $16 \mathrm{~S}$ rRNA sequences. In addition, the distribution ranges for the new species and $P$. gracilis are revisited, the advertisement call of $P$. gracilis is redescribed, and a discussion about the inapplicability of the synonyms available for $P$. gracilis is provided. 


\section{Material and methods}

Type specimens are deposited in the following herpetological collections: Museo Argentino de Ciencias Naturales "Bernardino Rivadavia"-CONICET (MACN), Buenos Aires, Argentina, and Laboratorio de Genética Evolutiva (LGE), Instituto de Biología Subtropical(CONICET-UNaM), Posadas, Misiones, Argentina. Additional examined specimens are deposited in Célio F. B. Haddad Collection (CFBH), Universidade Estadual Paulista, Campus Rio Claro, São Paulo, Brazil (Appendix I).

Specimens collected for this study were deeply anesthetized with lidocaine, fixed in $10 \%$ formalin followed by long-term storage in $70 \%$ ethyl alcohol. Eleven morphometric variables were measured for each specimen. Nine variables follow Duellman (1970): snout-vent length (SVL), head length (HL), head width (HW), eye diameter (ED), interorbital distance (IOD), internarial distance (IND), tympanum diameter (TD), tibia length (TL), and foot length (FL), while thigh length (THL) follows Heyer et al. (1990). All measurements are in millimeters and were taken with a digital caliper to the nearest $0.1 \mathrm{~mm}$. Sex was determined by visual inspection of secondary sexual characters, such as nuptial pads or extended vocal sacs in males and presence of ovarian follicles in females.

We analyzed 19 advertisement calls obtained from three unvouchered males of Physalaemus gracilis, from Montevideo, Uruguay on 26 February 2003, between 1:27-1:50 hours. (Air temperature $[A T]=20.5^{\circ} \mathrm{C}$; Water temperature $[\mathrm{WT}]=21.5^{\circ} \mathrm{C}$ ). In addition, 20 advertisement calls from two unvouchered males of Physalaemus $\mathbf{s p}$. nov. were recorded in two localities in Misiones province, Argentina. One of them, recorded on 28 April 2007 (at 19:30 h) in Parque Provincial El Piñalito, San Pedro, Misiones province, Argentina (AT $=18^{\circ} \mathrm{C}$; WT $=13^{\circ} \mathrm{C}$ ). The other was recorded on 22 September 2007 (at 21:30 h) in the vicinity of Santa Rita, 25 de Mayo, Misiones province, Argentina $\left(\mathrm{AT}=19^{\circ} \mathrm{C} ; \mathrm{WT}=19^{\circ} \mathrm{C}\right)$. Advertisement calls were recorded with a SONY TCM359 tape recorder with a Sennheiser ME 66 directional microphone. The recordings were digitized and analyzed with Sound Forge Pro 11 at $44.1 \mathrm{kHz}, 16$ bits of resolution, and mono channel (FFT $=256$ points resolution). The following temporal parameters were measured from the waveform: call duration, fundamental frequency, and dominant frequency. The harmonics structure was obtained from spectrograms, and the call rate (calls per minute) was calculated. Terminology for advertisement call descriptions follows Cocroft and Ryan (1995).

To estimate genetic distances between Physalaemus sp. nov. and related ones (i.e., the species of the $P$. gracilis group), sequences of a fragment of the mitochondrial 16S rRNA gene were obtained from GenBank (P. barrioi KP146066-7; P. evangelistai KP 146069; P. gracilis AY680272, DQ283417, KP146073; P. jordanensis KP146070; P. lisei KP146074-5, and Physalaemus sp. nov. KP146072) and aligned in MAFFT (Katoh \& Toh, 2008) under the strategy G-INS-i. The aligned dataset comprised 524 base pairs and uncorrected pairwise distances were calculated using PAUP* (Swofford, 2002).

\section{Results and discussion}

Genetic distance in the Physalaemus gracilis group. The analysis of the uncorrected pairwise $p$-distances showed a difference in the interspecific distance values among the analyzed species ranging from $2.15 \%$ to $9.76 \%$ (Table 1). The observed uncorrected $p$-distances among Physalaemus sp. nov. and its more related species (i.e., $P$. jordanensis and P. barrioi, see Lourenço et al., 2015) is $\geq 2.15 \%$ and is consistent with genetic distances observed among other sister taxa of Physalaemus (see Lourenço et al. 2015; pers. obs.). Moreover, the genetic distance between Physalaemus sp. nov. and P. gracilis, the taxon historically confused with the new species, is the largest in the $P$. gracilis group ranging from $8.72 \%$ to $9.76 \%$.

The advertisement call of Physalaemus gracilis. The advertisement call of Physalaemus gracilis (Fig. 1) is composed by a single, non-pulsed note with descendant modulation. The spectrogram shows $7-11$ harmonics $(\mathrm{n}=$ 19). All harmonics are $S$ shaped, and with decreasing frequency modulation. The mean call duration is $0.97 \mathrm{~s}$ $(0.707-1.123 \mathrm{~s}, \mathrm{n}=19)$; fundamental frequency $472.63 \mathrm{~Hz}(452-493 \mathrm{~Hz}, \mathrm{n}=19)$, and dominant frequency $2455 \mathrm{~Hz}$ $(1811-2762 \mathrm{~Hz}, \mathrm{n}=19)$. Calls are given at a rate of 12.92 calls/minute $(6.60-18.50, \mathrm{n}=19)$. 
TABLE 1. Uncorrected pairwise distance ( $p$-distance) between Physalaemus carrizorum sp. nov. and related taxa of the P. gracilis species group.

\begin{tabular}{|c|c|c|c|c|c|c|c|c|c|c|}
\hline KP146072 & $\begin{array}{l}\text { P. sp. nov. LGE } \\
8877\end{array}$ & - & & & & & & & & \\
\hline KP146066 & $\begin{array}{l}\text { P. barrioi } \\
\text { ZUEC } 18147\end{array}$ & $2.15 \%$ & - & & & & & & & \\
\hline KP146067 & $\begin{array}{l}\text { P. barrioi } \\
\text { ZUEC } 18146\end{array}$ & $3.49 \%$ & $3.67 \%$ & - & & & & & & \\
\hline KP146070 & $\begin{array}{l}\text { P. jordanensis } \\
\text { CFBH } 9903\end{array}$ & $3.49 \%$ & $3.67 \%$ & $0.00 \%$ & - & & & & & \\
\hline KP146069 & $\begin{array}{l}\text { P. evangelistai } \\
\text { MNRJ } 55103\end{array}$ & $5.85 \%$ & $5.05 \%$ & $6.21 \%$ & $6.21 \%$ & - & & & & \\
\hline KP146073 & $\begin{array}{l}\text { P. gracilis } \\
\text { MHNM } 9511\end{array}$ & $8.72 \%$ & $8.72 \%$ & $10.05 \%$ & $10.05 \%$ & $8.34 \%$ & - & & & \\
\hline AY680272 & $\begin{array}{l}\text { P. gracilis } \\
\text { AJC95_228 }\end{array}$ & $9.76 \%$ & $9.58 \%$ & $11.11 \%$ & $11.11 \%$ & $10.16 \%$ & $6.21 \%$ & - & & \\
\hline DQ283417 & $\begin{array}{l}\text { P. gracilis } \mathrm{RdS} \\
788\end{array}$ & $8.72 \%$ & $8.72 \%$ & $10.05 \%$ & $10.05 \%$ & $8.34 \%$ & $0.00 \%$ & $6.21 \%$ & - & \\
\hline KР146074 & $\begin{array}{l}\text { P. lisei CFBH } \\
8527\end{array}$ & $8.90 \%$ & $7.93 \%$ & $8.70 \%$ & $8.70 \%$ & $7.35 \%$ & $7.90 \%$ & $7.77 \%$ & $7.90 \%$ & - \\
\hline KP146075 & $\begin{array}{l}\text { P. lisei LGE } \\
8878\end{array}$ & $8.90 \%$ & $7.93 \%$ & $8.70 \%$ & $8.70 \%$ & $7.35 \%$ & $7.90 \%$ & $7.77 \%$ & $7.90 \%$ & $\begin{array}{l}0.00 \\
\%\end{array}$ \\
\hline
\end{tabular}

\section{Physalaemus carrizorum, new species}

Synonyms

Paludicola gracilis Boulenger, 1883: Berg, 1896 (partim); Nieden, 1923 (partim); Miranda-Ribeiro, 1926 (partim).

Physalaemus gracilis (Boulenger, 1883): Parker, 1927 (partim); Freiberg, 1942 (partim); Cochran, 1955 (partim); Cei, 1956 (partim); Cei and Roig, 1961; Gallardo, 1961; Barrio, 1965 (partim); Gallardo, 1966; Cei, 1980 (partim); Frost, 1985 (partim); Cei, 1987 (partim); Langone, 1989 (partim); Gallardo and Varela, 1992 (partim); Klappenbach and Langone, 1992 (partim); Duellman, 1993 (partim); Langone, 1994 (partim); Achaval and Olmos, 1997 (partim); Lavilla et al., 2000 (partim); Lavilla and Cei, 2001 (partim); Nascimento et al., 2005 (partim).

Physalaemus aff. gracilis: Vaira et al., 2012.

Physalaemus sp. (aff. gracilis): Kwet, 2001.

Physalaemus sp.: Lourenço et al., 2015.

Holotype (fig. 2, table 2). MACN 35081 (adult male) collected on 10-18 February 1994 by J.C. Baciluk, J. Faivovich and M. López at "INTA, campo anexo cuartel Río Victoria” (2658'S, 54²9’W, datum WGS 84 ; 550 m above sea level [asl]), San Vicente, National Route 14 km. 1025, Departamento Guaraní, Misiones province, Argentina.

Paratopotypes (table 2). MACN 35082-4 (adult males) with the same data as holotype. MACN 49611-2 (adult males) collected on 5-18 January 1995 by J.C. Baciluk and J. Faivovich. MACN 50747 (adult male) collected on 12 December 2001 by J. Faivovich, S. Nenda, and A. Sehinkman. Paratypes (table 2). All the paratypes collected in Misiones province, Argentina at Departamento Cainguás: MACN 50755 (male) collected on October 1972 by A. Barrio and J. Poirot at Arroyo Moncholito and Arroyo Central, General Belgrano. MACN 50757 (female) collected on 14 September 1971 by J. Foerster at 2 de Mayo (27²'23”S, 5440’30”W; 505 m asl).

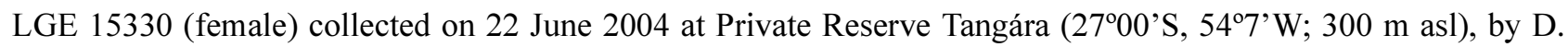
Cardozo and M. Giménez. Departamento General Manuel Belgrano: MACN 30156 (male) collected on 10 August 1972 by C. and M. Stiebel, MACN 50748 (female) collected on 11 March 1969 by A. Barrio, and MACN 50749 (male) collected on 25 January 1971 by J. Enriquez, at Bernardo de Irigoyen (26¹5'16"S, 53³8'50"W, 815 m asl), MACN 50750 (male) collected on 17 October 1971 by A. Barrio, MACN 50751 (male) collected on October 1972 by A. Barrio and J. Poirot, MACN 50752-4 (males) and 50756 (female) collected on 17 October 1971 by 
"Comisión Vertebrados FCEN", and MACN50758-75 (females, males) collected on 12 October 1971 by "Comisión Vertebrados FCEN", at Arroyo Moncholito (26³'06"S, 5349'56"W; 497 m asl. Departamento San Pedro: MACN 34103 (male) collected on 5 August 1985 by T. Waller, and MACN 40763 (male) collected on 26 September 2010 by B.L. Blotto, L. Nicoli, M.O. Pereyra, and A. Sehinkman, at Parque Provincial Cruce Caballero

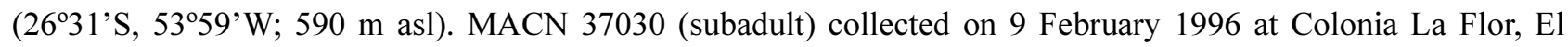

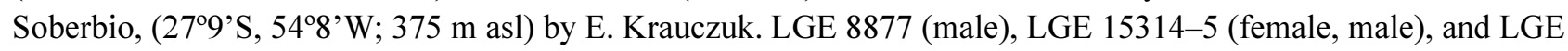
15317-23 (seven males) collected on 27-30 August 2005 at Parque Provincial Moconá (27¹0'S, 53⒌'W; $250 \mathrm{~m}$ asl), El Soberbio by E. Krauczuk. LGE 15316 (male) collected on 21 June 2009 by E. Krauczuk, LGE 15324 (male) collected on 28 April 2007 by D. Baldo, E. Castillo, and M.O. Pereyra, and LGE 15656 and 15659 (juveniles) collected on 12 February 2001 by D. Baldo and E. Krauczuk, at Parque Provincial El Piñalito, San Pedro (265'33"S, 5350'21"W; $760 \mathrm{~m}$ asl). Departamento 25 de Mayo: LGE 15325-328 (two males, two females) collected on 22 September 2007 at Puerto Londero, intersection Arroyo Los Muertos and Provincial

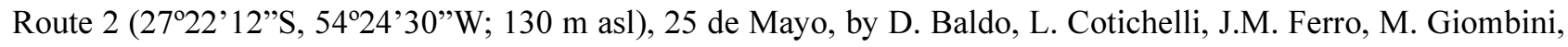
and M.O. Pereyra.

TABLE 2. Morphometric measurements of the holotype (MACN 35081), and the type series. Standard deviation (SD).

\begin{tabular}{|c|c|c|c|c|c|c|c|c|c|}
\hline \multirow{3}{*}{$\begin{array}{l}\text { Sex } \\
\text { Snout vent Length (SVL) }\end{array}$} & \multirow{3}{*}{$\begin{array}{l}\text { Holotype } \\
\text { Male }\end{array}$} & \multicolumn{4}{|c|}{ Paratypes } & \multicolumn{4}{|c|}{ Paratypes } \\
\hline & & \multicolumn{4}{|c|}{ Males $(n=20)$} & \multicolumn{4}{|c|}{ Females $(n=4)$} \\
\hline & & 32.0 & \pm & 2.6 & $(27.4-36.7)$ & 34.0 & \pm & 1.5 & $(31.5-35.1)$ \\
\hline Head Length (HL) & 10.1 & 10.6 & \pm & 1.1 & $(8.8-12.2)$ & 11.2 & \pm & 1.0 & $(10.1-12.7)$ \\
\hline Head width (HW) & 9.5 & 9.8 & \pm & 0.8 & $(8.6-11.2)$ & 10.0 & \pm & 0.7 & $(9.5-11.2)$ \\
\hline Eye diameter (ED) & 3.1 & 2.9 & \pm & 0.2 & $(2.7-3.3)$ & 3.1 & \pm & 0.1 & $(2.9-3.2)$ \\
\hline Tympanum diameter (TD) & 2.0 & 2.0 & \pm & 0.2 & $(1.4-2.2)$ & 1.9 & \pm & 0.1 & $(1.9-2.0)$ \\
\hline Interorbital distance (IOD) & 2.6 & 2.7 & \pm & 0.3 & $(2.3-3.3)$ & 2.9 & \pm & 0.4 & $(2.4--3.4)$ \\
\hline Internarial distance (IND) & 2.3 & 2.2 & \pm & 0.1 & $(2.1-2.5)$ & 2.1 & \pm & 0.1 & $(2.0-2.3)$ \\
\hline Tibia length (TL) & 14.9 & 15.1 & \pm & 0.9 & $(13.8-17.8)$ & 15.9 & \pm & 0.8 & $(14.9-17.0)$ \\
\hline Thigh length (THL) & 14.3 & 13.5 & \pm & 0.6 & $(12.3-14.3)$ & 14.7 & \pm & 0.4 & $(14.3-15.2)$ \\
\hline Foot length (FL) & 17.0 & 16.9 & \pm & 1.0 & $(15.3-19.1)$ & 17.8 & \pm & 0.8 & $(16.7-19.0)$ \\
\hline
\end{tabular}

Diagnosis. Physalaemus carrizorum sp. nov. is diagnosed by a combination of morphological and acoustic characters: 1) large size (mean SVL (mm) = 32.0 males; 34.0 females); 2) slender body aspect; 3 ) head longer than wide; 4) supratympanic fold developed, curved toward the arm insertion; 5) A light median stripe on throat, chest, and/or abdomen; 6) medium sized inguinal glands; 7) tarsal tubercle present; 8) supernumerary tubercles on hands and feet; 9) advertisement call non-pulsed, with descendant frequency modulation;10) call duration $2.40 \mathrm{~s}$ (2.246$2.513 \mathrm{~s})$; 11) fundamental frequency $2270.33 \mathrm{~Hz}(2179-2361 \mathrm{~Hz})$.

Comparison with other species. The new species could be differentiated from all the species of Physalaemus not belonging to the $P$. gracilis group (see Lourenço et al., 2015) by having a median stripe defined by the absence of melanocytes on throat, chest, and/or abdomen which is a putative synapomorphy of the $P$. gracilis group. The only exception is $P$. riograndensis, of the $P$. biligonigerus group, that have a similar pattern (Milstead, 1960) with an independent phylogenetic origin (see Lourenço et al., 2015: fig. 4-5). However, the new species clearly differs from $P$. riograndensis in having inguinal glands, larger adult size ( $>25 \mathrm{~mm}$ vs. $<20.5 \mathrm{~mm}$ ), and a dorsal skin texture near smooth (vs. tuberculate in P. riograndensis). Physalaemus carrizorum sp. nov. could be differentiated from the remaining species of the $P$. gracilis group by the presence of a supratympanic fold developed, curved towards the arm insertion (supratympanic fold poorly developed in $P$. barrioi, Provete et al., 2012; supratympanic fold not evident in $P$. evangelistai, . gracilis, $P$. lisei, and P. jordanensis). In addition, the largest SVL (mm) (27.4-36.7 males; 31.5-35.1 females, table 2) separates $P$. carrizorum sp. nov. from $P$. evangelistai: $21.5-23.0 \mathrm{~mm}$ in males (Bokermann, 1967); P. lisei: 23.1-25.0 mm in males, 24.2-29.0 mm in females (Braun \& Braun, 1977), $P$. jordanensis $24.0 \mathrm{~mm}$ in holotype (male), $27.0 \mathrm{~mm}$ in allotype (female) (Bokermann, 1967).

Physalaemus carrizorum sp. nov. presents longer call duration $(2.148-2.880$ s.) than P. barrioi $(1.030-1.720$ s., Provete et al., 2012), P. evangelistai (1.0-1.2 s.; Bokermann, 1967), P. jordanensis (0.62-1.204 s; Giaretta et al., 
2009), and $P$. gracilis (0.707-1.123 s.; this work). The new species can be distinguished from $P$. jordanensis by the absence of pulsed notes (pulsed advertisement call in P. jordanensis; Bokermann, 1967; Giaretta et al., 2009), and from P. lisei by having descendant modulation of the call (ascendant modulation in P. lisei, Morais \& Kwet, 2012).

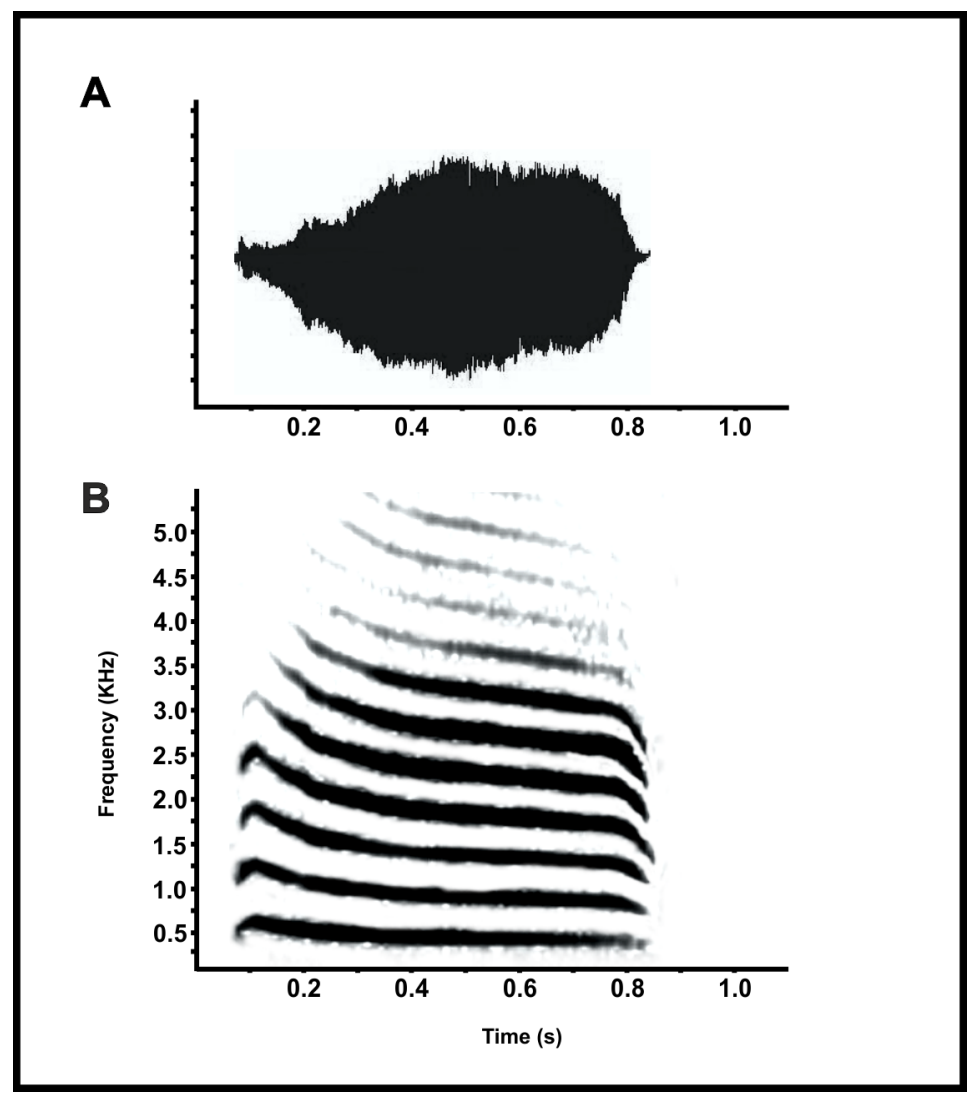

FIGURE 1. Advertisement call of Physalaemus gracilis. A) Sonogram. B) Spectrogram. Time in seconds (s). Frequency in KiloHertz (KHz).

Description of holotype (fig. 2). Slender body aspect. Narrow head, longer than wide (HL/HW=1.1). Snout long, subacuminate in dorsal view, protruding from the jaw in lateral view. Eyes slightly protuberant. Pupil horizontal. Tongue piriform and free. Vomerine teeth absent, maxillary teeth present. Canthus rostralis rounded. Loreal region concave. Tympanic annulus visible under skin, tympanic membrane poorly evident. Supratympanic fold pronounced, curved towards arm insertion. Dorsum with small glands arranged in longitudinal irregular folds, with some isolated rounded glands in the head, eyelids and the sacral region. Inguinal glands, medium sized, rounded not prominent. A thin urostilar vertebral line is evident. Ventral surface smooth, with flat granules in thighs. Vocal sac well-developed, with lateral folds. Arms short, fingers without fringes or webbing. Length of the fingers II $=\mathrm{V}<$ III $<$ IV. Prominent metacarpal tubercles: external rounded, internal ovoid. Evident subarticular tubercles on hands, with numerous and prominent supernumerary tubercles. Nuptial pad on thumbs, covering the inner region of the internal metacarpal tubercle. Tibia longer than femur. Finger and toe tips not expanded. Toes formula $\mathrm{I}<\mathrm{II}<\mathrm{V}<\mathrm{III}<\mathrm{IV}$. External metatarsal tubercle small, internal metatarsal tubercle ovoid. Tarsal tubercle, small and rounded. Tarsal fold poorly developed. Subarticular tubercles developed, multiple and prominent plantar supernumerary tubercles.

Measurements of holotype (in mm). SVL 31.5; HL 10.1; HW 9.5; ED 3.1; TD 2.0; IOD 2.6; IND 2.3; TL 14.9; THL 14.3; FL 17.0. 


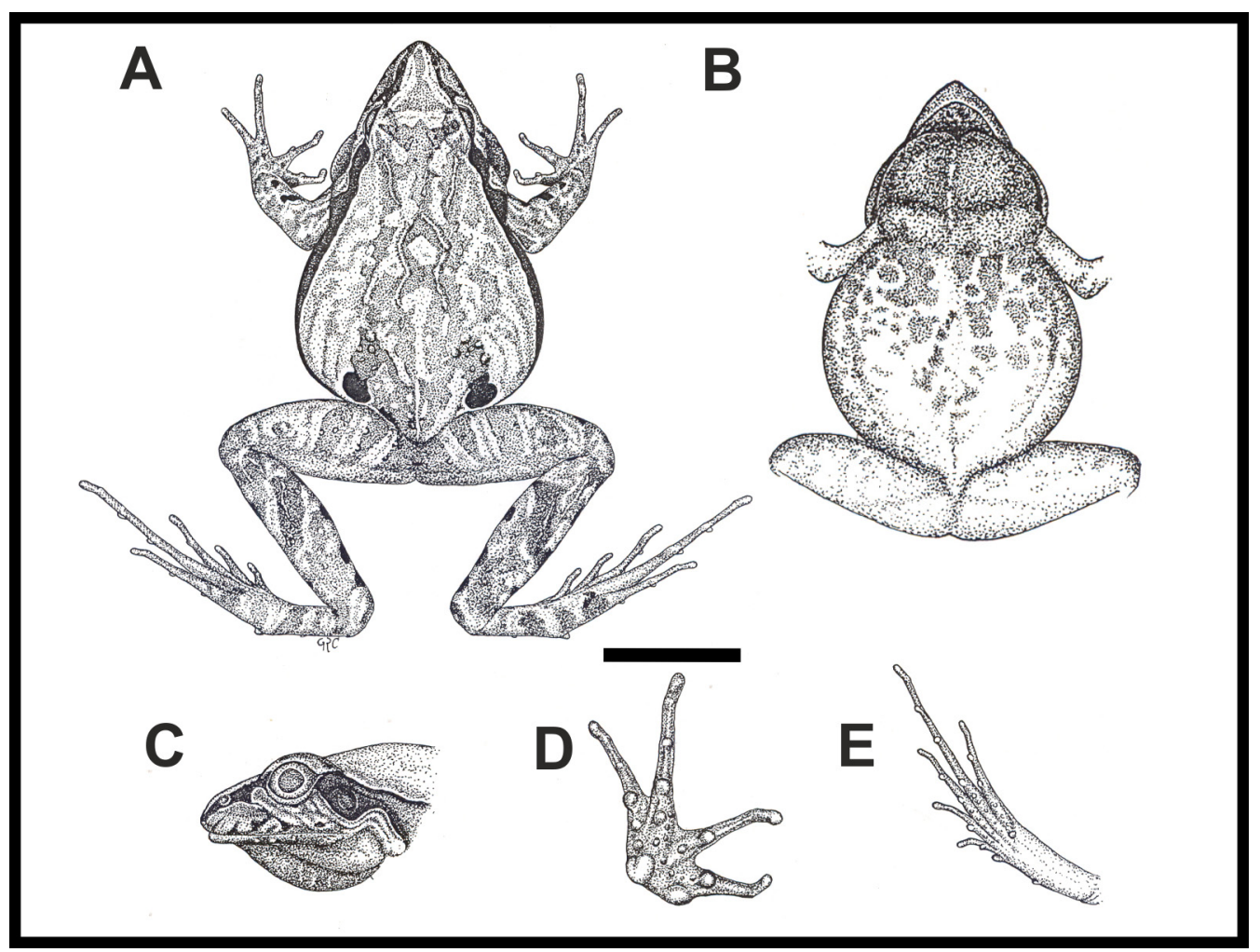

FIGURE 2. Physalaemus carrizorum sp. nov., holotype, MACN 35081. A) Dorsal view, and B) ventral view of the body; C) lateral view of the head; D) palmar view of hand; E) plantar view of foot. Scale bar $1 \mathrm{~cm}$.

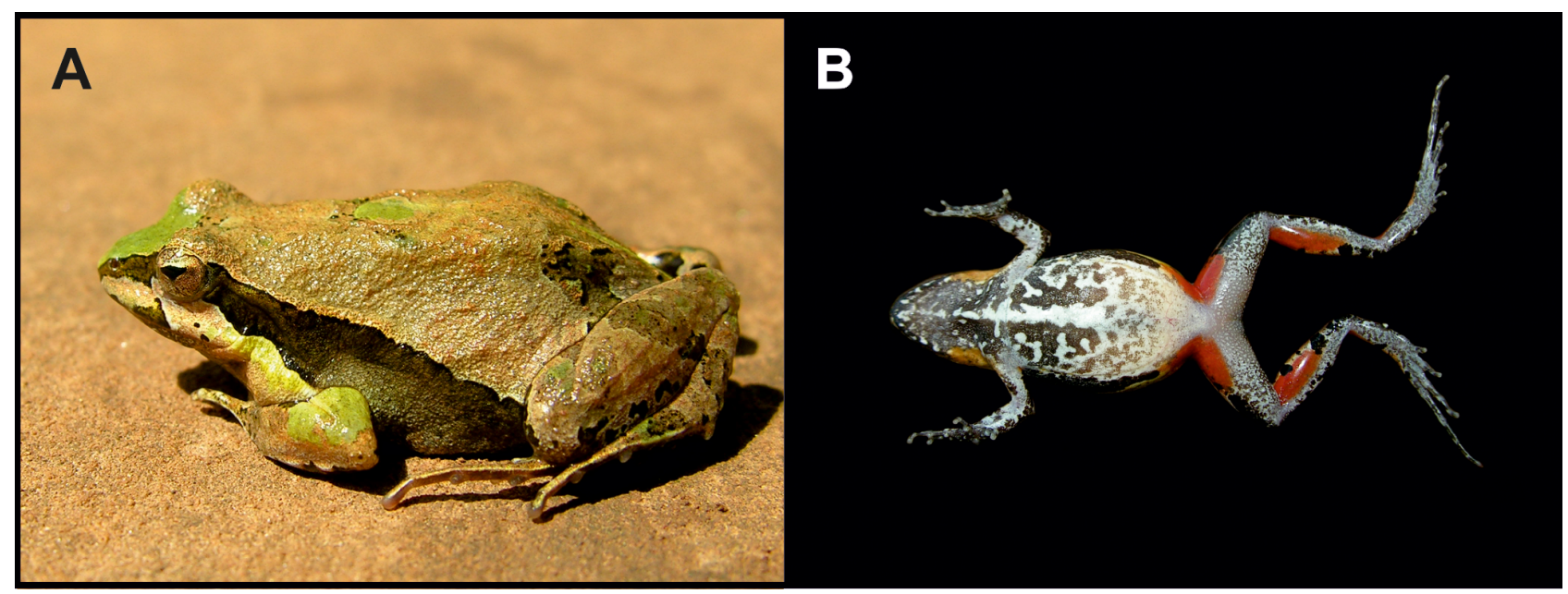

FIGURE 3. Physalaemus carrizorum sp. nov. in life. A) Paratype LGE 15320; B) ventral view of the paratype LGE 15325.

Color in preservative. The holotype and the rest of the specimens examined vary in the dorsum coloration from brown pale to grayish, with the anterior region of the head lighter (dorsal view). Urostilar vertebral line thin and whitish. Inguinal gland black, delimited by a white border. Anterior limbs with similar pattern than dorsum, with a dark irregular spot at the inner portion in the middle of the forearms. Dorsum of posterior limbs with dark bars crossing the femur and tibia. In lateral view, the head is light with a thin dark stripe at the tip of the snout and a dark stripe extending from postorbital region to groin, bordered by small white spots. In addition, the dorsal pattern could be with irregular shapes, tending to form a dorsal ovoid spot in the middle of the pectoral girdle, or homogenous without a defined pattern.

As in living specimens, the belly presents the gular region, chest, and posterior region of the abdomen densely spotted (marbled) dark brown on a whitish background, with the posterior region of the abdomen less spotted. An irregular stripe in the ventral region could be extended from the mental region to the middle of abdomen in some 
specimens (fig. 3B), whereas in others, this stripe is minimally discernible or not evident in the abdominal region (fig. 2B) or throat. This line is not evident in specimens MACN 50751, and 50770. In some males, the lateral region of the vocal sac is light brown, and the withe spot bordering the mandibular are less evident. In addition, the reddish coloration present in thighs, inguinal region and tibia disappear in preservative. All males have beige to light brown colored nuptial pads.

Variation. Scant variation is observed between the holotype and the rest of the specimens examined. The lateral and ventral pattern is constant. However, the dorsal skin is nearly smooth in some paratypes (LGE 15315, 15319), while in others could be observed some isolated granules in eyelids and head (LGE 15314, 15321), dispersed through the dorsum (LGE 15320), or flanking the urostilar vertebral line (LGE 8877, 15326). Most of specimens have uniformly brownish dorsum, with the antero dorsal region of the head lighter brown or green (fig. 3A). All specimens have a thin urostilar vertebral line, from the cloacal to the pelvic region. This urostilar vertebral line is white in most of specimens, but green in those specimens that have the dorsal region of the head green. The inguinal region, outer portion of thigh and inner of tibia are reddish (ventral view, fig. 3B). The black inguinal spots are bordered with yellow. An irregular dark brown interorbital spot is present in some specimens. In ventral view, the gular region, chest, and posterior region of the abdomen are always densely spotted on a white background, with the posterior region of the abdomen less spotted. An irregular stripe in the ventral region is defined by the absence of melanocytes in the medial line. In some males, the lateral region of the vocal sac is brown, and the border of the mandibular is densely spotted with white dots (fig. 3B). All males have beige to light brown nuptial pads.

Advertisement call (fig. 4). The advertisement call of Physalaemus carrizorum sp. nov. $(n=20)$ is composed by a single, long, and non-pulsed note, with a slightly descendant modulation. With the equipment used, we detected between 7-12 S-shaped harmonics, with decreasing frequency modulation. The mean call duration is 2.40 s $(2.246-2.513 \mathrm{~s})$; fundamental frequency $432.67 \mathrm{~Hz}(409-455)$, and dominant frequency $2270.33 \mathrm{~Hz}(2179-$ 2361). Calls are given at a rate of 7.21 calls/minute (4.83-10.11).

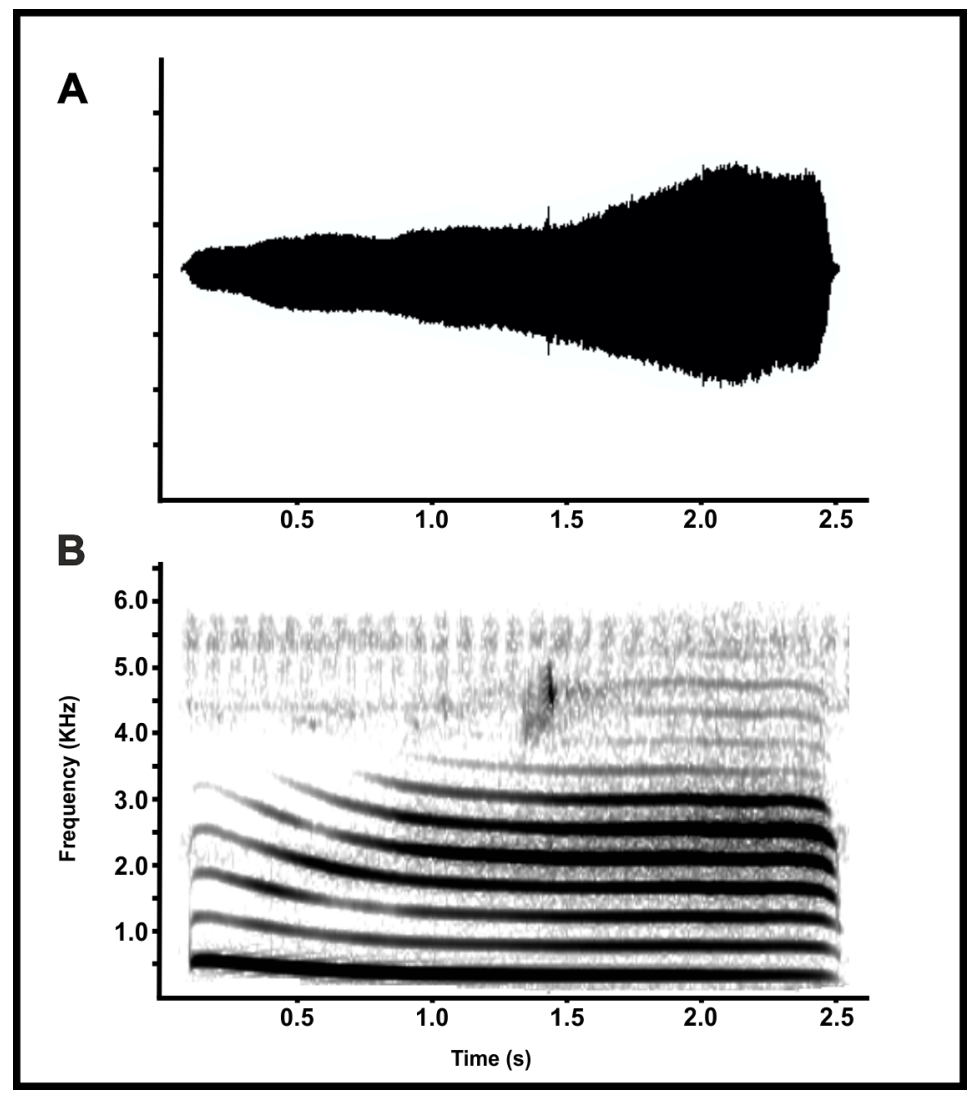

FIGURE 4. Advertisement call of Physalaemus carrizorum sp. nov. A) Sonogram. B) Spectrogram. Time in seconds (s). Frequency in KiloHertz (KHz). 
Geographic distribution. Physalaemus gracilis (Boulenger, 1883), was first cited for Argentina (Misiones and Buenos Aires provinces, as Paludicola gracilis) by Berg (1896) without reference specimens. In subsequent lists of amphibians of Argentina, some authors continued using Berg's reference (Freiberg, 1942; Cei, 1956). Cei and Roig (1961) and Barrio (1965) presented new data and reported specimens from Misiones province as Physalaemus gracilis. Subsequent works (e.g., Cei, 1980, 1987; Gallardo, 1966; Gallardo \& Varela, 1992; Lavilla et al., 2000; Lavilla \& Cei, 2001) cited P. gracilis for Argentina based on those reports. Barrio (1965) also cited this species for Corrientes province, but provided no reference specimens. No voucher specimens from Corrientes are currently deposited in Barrio's herpetological collection (Ex CENAI, now in MACN). Gallardo (1966) and Contreras and Contreras (1982) also mentioned this species for some localities in Corrientes province but they did not provide voucher information. Contreras (1982) reported P. gracilis for Chaco Province, but all the reported specimens correspond to P. biligonigerus. Based on the specimens examined by us, we found that Physalaemus carrizorum sp. nov. is present in Argentina only in some localities of Misiones province (fig. 5). The species is likely to occur in neighboring Brazil. For instance, the advertisement call assigned to $P$. aff. gracilis from PróMata, Rio Grande do Sul state (Kwet, 2001) match the call duration length of P. carrizorum sp. nov. However, the quality of the advertisement call is poor, and the taxonomic status of this population should be reassessed. In the same way, the voucher specimen USMN 103684 cited as . gracilis for Nova Teutônia, Santa Catarina, Brazil, by Cochran (1955) have similar morphological traits than P. carrizorum sp. nov. being tentatively assigned to the new species.

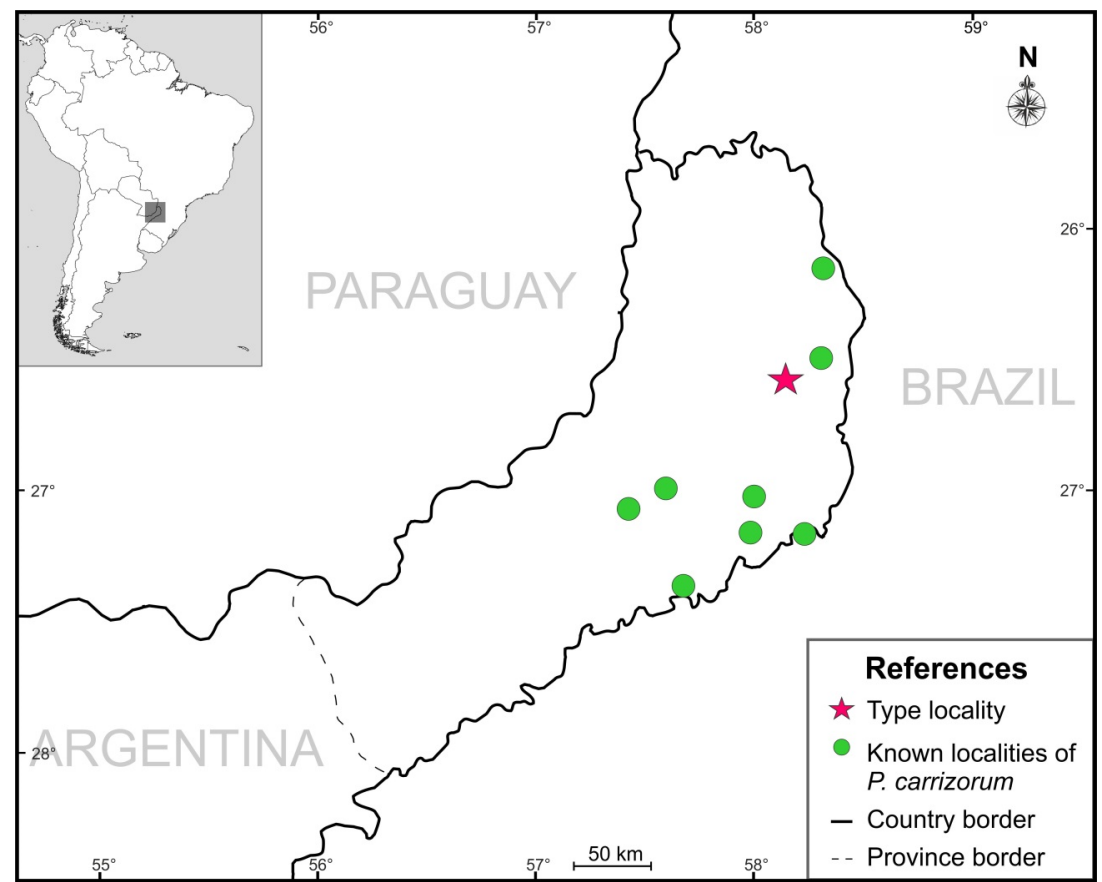

FIGURE 5. Geographic distribution of Physalaemus carrizorum sp. nov.

Etymology. The new species is dedicated to Gustavo R. Carrizo and his sons, Rodrigo and Ramiro Carrizo.

Remarks. Barrio (1965) described the advertisement call of Physalaemus gracilis from Oberá, Misiones, Argentina, presenting a spectrogram (Barrio, 1965; Lam. V. 6), but in the Specimens Examined Section, only one voucher from Argentina (Tobuna, Misiones province) is referred (MACN 2967). However, the characteristics of this advertisement call, for example call duration (0.9-1.0 s) and dominant frequency $(4000-5000 \mathrm{~Hz})$, diverge remarkably from those of $P$. carrizorum sp. nov. (2.246-2.513 s and 2179-2361 Hz respectively). The analyzed advertisement call from Montevideo, Uruguay (this work) shares with Barrio's spectrogram the length of the advertisement call. However, the dominant and fundamental frequencies are not in concordance with those of $P$. gracilis, or with any species of Physalaemus present in Argentina, although this could be consequence of the equipment used to record the advertisement call and the methodology employed in the analysis. Since Barrio (1965) reported having heard the call of $P$. gracilis in Uruguay and Rio Grande do Sul (Brazil), we believe that the recording used for his call description may belong to a specimen of this species from those places, and does not belong to $P$. carrizorum sp. nov. 


\section{Comments about the available names which could be applicable to this species}

Four species names, currently considered synonyms of Physalaemus gracilis, and which could be applicable to the new species, are available. Since P. carrizorum sp. nov. was historically confused with this taxon, a review of these names was performed:

Paludicola ranina Cope, 1885. Type locality: "Sao Joao do Monte Negro". Vanzolini (1953) stated it as "São João do Monte Negro in Rio Grande do Sul near Porto Alegre" (Brazil). The genetic distance between Physalaemus carrizorum sp. nov. and P. gracilis from Porto Alegre (GenBank accession number AY680272) of more than $9 \%$, and the geographic proximity between Montenegro and Porto Alegre (nearly $50 \mathrm{~km}$ in straight line), suggest that the specimens from Montenegro correspond to $P$. gracilis, and P. ranina still has to be considered as a synonym of $P$. gracilis.

Paludicola bischoffi Boulenger, 1887. Type locality: "Mundo Novo, Rio Grande do Sul". As noted by Parker (1927) and Klappenbach and Langone (1992) the specimens described by Boulenger (1887) as Paludicola bischoffi lack inguinal glands. The presence of medium sized inguinal glands is a common character of all known species of the Physalaemus gracilis species group (see Nascimento et al., 2005). In this sense, as was previously mentioned by Parker (1927), P. bischoffi should be considered a synonym of P. cuvieri, a common species in Rio Grande do Sul, Brazil (Braun \& Braun, 1980; Kwet, 2001).

Liuperus calcaratus Philippi, 1902. Type locality: "Montevideo", Uruguay. It was considered a synonym of Physalaemus gracilis by Parker (1927), based on morphological characters, and later such assumption confirmed by Klappenbach (1968). In the same way, Pleurodema montevidense Philippi, 1902 (type locality: "Montevideo", Uruguay) was considered a synonym of $P$. gracilis by Klappenbach (1968). The specimens from Montevideo, Uruguay, differ morphologically from $P$. carrizorum sp. nov. (see diagnosis) and present a shorter advertisement call (this work). Besides, the genetic distance between $P$. carrizorum sp. nov. and $P$. gracilis from Uruguayan populations is large (more than $8 \%$ ), which indicates that $L$. calcaratus and $P$. montevidense are synonyms of $P$. gracilis.

\section{Acknowledgments}

The authors thank D. Baldo, J. Faivovich, F. Kolenc and an anonymous reviewer for comments to improve the manuscript. We acknowledge Gustavo R. Carrizo who kindly allowed us to describe the new species and made the drawings (figure 2). The authors are thankful to CONICET and ANPCyT PICTs 2013-404, 2014-1343, 2015-813, and 2015-820 for financial support.

\section{References}

Achaval, F. \& Olmos, A. (1997) Anfibios y reptiles del Uruguay. Serie Fauna, 1, 1-128.

Barrio, A. (1965) El género Physalaemus (Anura, Leptodactylidae) en la Argentina. Physis, 25, 421-444.

Berg, C. (1896) Batracios Argentinos, Enumeración sistemática, sinonímica y bibliográfica de los batracios de la República Argentina. Anales del Museo Nacional de Historia Natural de Buenos Aires, 5, 147-226.

Bokermann, W.C.A. (1967) Tres novas espécies de Physalaemus do sudeste brasileiro (Amphibia, Leptodactylidae). Revista Brasileira de Biologia, 27, 135-143.

Boulenger, G.A. (1883) Notes on little-known species of frogs. Annals and Magazine of Natural History, 11, 16-19. https://doi.org/10.1080/00222938309459087

Boulenger, G.A. (1887) Descriptions of new or little-known South-American frogs of the genera Paludicola and Hyla. Annals and Magazine of Natural History, Series 5, 20, 295-300.

Braun, P.C. \& Braun, C.A.S. (1977) Nova espécie de Physalaemus do estado do Rio Grande do Sul, Brasil (Anura, Leptodactylidae). Revista Brasileira de Biologia, 37, 867-871.

Braun, P.C. \& Braun, C.A.S. (1980) Lista prévia dos anfíbios do Estado do Rio Grande do Sul, Brasil. Iheringia, Série Zoologia, 56, 121-146.

Cei, J.M. (1956) Nueva lista sistemática de los Batracios de Argentina y breves notas sobre su biología y ecología. Investigaciones Zoológicas Chilenas, 3, 35-77.

Cei, J.M. (1980) Amphibians of Argentina. Monitore Zoologico Italiano (NS) Monografia, 2, 1-609.

Cei, J.M. (1987) Additional Notes to "Amphibians of Argentina": an update, 1980-1986. Monitore Zoologico Italiano, 21, 
209-272.

Cei, J.M. \& Roig, V.G. (1961) Batracios recolectados por la Expedición Biológica Erspamer en corrientes y selva oriental de Misiones. Notas Biológicas de la Facultad de Ciencias Exactas, Físicas y Naturales, Corrientes, Zoología, 1, 1-40.

Cochran, D.M. (1955 “1954”) Frogs of southeastern Brazil. Bulletin of the United States National Museum, $206,1-423$.

Cocroft, R.B. \& Ryan, M.J. (1995) Patterns of advertisement call evolution in toads and chorus frogs. Animal Behaviour, 49 , 283-303. https://doi.org/10.1006/anbe.1995.0043

Contreras, A.C. (1982) Incorporación de Physalaemus gracilis (Boulenger, 1883) a la batracofauna de la provincia del Chaco, Argentina. Historia Natural, 2, 192.

Contreras, J.R. \& Contreras, A.C. (1982). Características ecológicas y biogeográficas de la batracofauna del noroeste de la provincia de Corrientes, Argentina. Ecosur, 9, 29-66.

Cope, E.D. (1885 "1884") Twelfth contribution to the herpetology of tropical America. Proceedings of the American Philosophical Society, 22, 167-194.

Duellman, W.E. (1970) The hylid frogs of Middle America. Monograph. Museum of Natural History, University of Kansas, 1$2,1-753$.

Duellman, W.E. (1993) Amphibian species of the world: additions and corrections. Special Publication. Natural History Museum, University of Kansas, 21, 1-372.

Freiberg, M.A. (1942) Enumeración sistemática y distribución geográfica de los batracios argentinos. Physis, 19, $219-240$.

Frost, D.R. (1985) Amphibian species of the world: a taxonomic and geographic reference. Association of Systematic Collections and Allen Press, Lawrence, KS, $732 \mathrm{pp}$.

Frost, D.R. (2017) Amphibian Species of the World: an Online Reference. Version 6.0. American Museum of Natural History, New York, USA. Electronic Database accessible. Available from: http://research.amnh.org/herpetology/amphibia/ index.html (accessed 30 September 2017)

Gallardo, J.M. (1961) Anfibios Anuros de Misiones con la descripción de una nueva especie de Crossodactylus. Neotropica, 7 , 33-38.

Gallardo, J.M. (1966) Zoogeografía de los Anfibios chaqueños. Physis, 26, 67-81.

Gallardo, J.M. \& Varela, E.A. (1992) Anfibios de la República Argentina: Ecología y comportamiento. Fauna de agua dulce de la República Argentina. La Plata, 41, 1-116.

Giaretta, A.A., Martins, L.B. \& Santos, M.P. (2009) Further notes on the taxonomy of four species of Physalaemus (Anura, Leiuperidae) from the Atlantic Forest of Southeastern Brazil. Zootaxa, 2266, 51-60.

Heyer, W.R., Rand, A.S., Cruz, C.A.G., Peixoto, O.L. \& Nelson, C.E. (1990) Frogs of Boracéia. Arquivos de Zoologia, 31, 231410.

Katoh, K. \& Toh, H. (2008) Recent developments in the MAFFT multiple sequence alignment program. Briefing in Bioinformatics, 9, 276-285. https://doi.org/10.1093/bib/bbn013

Klappenbach, M.A. (1968) Notas herpetológicas, III. Identificación de las especies uruguayas descriptas por Philippi en el "Suplemento a los Batraquios chilenos". Investigaciones Zoológicas Chilenas, 23, 147-151.

Klappenbach, M.A. \& Langone, J.A. (1992) Lista Sistemática y Sinonímica de los Anfibios del Uruguay. Anales del Museo Nacional de Historia Natural de Montevideo, 8, 163-222.

Kwet, A. (2001) Frösche im brasilianischen Araukarienwald-Anurengemeinschaft des Araukarienwaldes von Rio Grande do Sul: Diversität, Reproduktion und Ressourcenaufteilung. Natur und Tier-Verlag, Münster, 192 pp.

Langone, J.A. (1989) Descripción de la larva de Physalaemus gracilis (Boulenger, 1883) (Amphibia, Anura, Leptodactylidae). Comunicaciones Zoológicas del Museo de Historia Natural de Montevideo, 171, 1-11.

Langone, J.A. (1994) Ranas y sapos del Uruguay (reconocimientos y aspectos biológicos). Museo Damaso Antonio Larrañaga, Serie de Divulgación, 5, 1-123.

Lavilla, E.O. \& Cei, J.M. (2001) Amphibians of Argentina, A Second Update, 1987-2000. Museo Regionale di Scienze Naturali. Torino, 28, 1-177.

Lavilla, E.O., Ponssa, M.L., Baldo, D., Basso, N., Bosso, A., Céspedez, J., Chébez, J.C., Faivovich, J., Ferrari, L., Lajmanovich, R., Langone, J.A., Peltzer, P., Ubeda, C., Vaira, M. \& Vera Candioti, F. (2000) Categorización de los anfibios de Argentina. In: Lavilla, E.O, Richard, E. \& Scrocchi, G.J. (Eds.), Categorización de los anfibios y reptiles de la República Argentina. Asociación Herpetológica Argentina, Tucumán, pp. 11-34.

Lourenço, L.B., Targueta, C.P., Baldo, D., Nascimento, J., Garcia, P.C.A., Andrade, G.V., Haddad, C.F.B. \& Recco-Pimentel, S.M. (2015) Phylogeny of frogs from the genus Physalaemus (Anura, Leptodactylidae) inferred from mitochondrial and nuclear gene sequences. Molecular Phylogenetics and Evolution, 92, 204-216. https://doi.org/10.1016/j.ympev.2015.06.011

Lynch, J.D. (1970) Systematic status of the american leptodactylid frog genera Engystomops, Eupemphix and Physalaemus. Copeia, 1970, 488-496. https://doi.org/10.2307/1442276

Milstead, W.W. (1960) Frogs of the genus Physalaemus in southern Brazil with the description of a new species. Copeia, 1960, 83-89.

https://doi.org/10.2307/1440198 
Miranda-Ribeiro, A. (1926) Notas para servirem ao estudo do gymnobatrachios (Anura) brasileiros. Archivos do Museu Nacional do Rio de Janeiro, 27, 1-227.

Morais, A.R. \& Kwet, A. (2012) Description of the advertisement call of Physalaemus lisei (Anura: Leiuperidae). Salamandra, 48, 227-229.

Nascimento, L.B., Caramaschi, U. \& Cruz, C.A.G. (2005) Taxonomic review of the species groups of the genus Physalaemus Fitzinger, 1826 with revalidation of the genera Engystomops Jiménez de la Espada, 1872 and Eupemphix Steindachner, 1863 (Amphibia, Anura, Leptodactylidae). Arquivos do Museu Nacional, 63, 297-320.

Nieden, F. (1923) Anura I. Subordo Aglossa und Phanerglossa sectio 1 Arcifera. Das Tierreich, 46, 1-584.

Parker, H.W. (1927) A revision of the frogs of the genera Pseudopaludicola, Physalaemus, and Pleurodema. Annals and Magazine of Natural History, Series 9, 20, 450-478.

Philippi, R.A. (1902) Suplemento a los Batraquios Chilenos Descritos en la Historia Física i Política de Chile de don Claudio Gay. Libreria Alemana de Jose Ivens, Santiago de Chile, $161 \mathrm{pp.}$

Provete, D.B., Garey, M.V., Toledo, L.F., Nascimento, J., Lourenço, L.B., Rossa-Feres, D.C. \& Haddad, C.F.B. (2012) Redescription of Physalaemus barrioi (Anura: Leiuperidae). Copeia, 2012, 507-518. https://doi.org/10.1643/CH-10-142

Ron, S.R., Coloma, L.A. \& Cannatella, D.C. (2005) A new, cryptic species of Physalaemus (Anura: Leptodactylidae) from western Ecuador with comments on the call structure of the P. pustulosus species group. Herpetologica, 61, 178-198. https://doi.org/10.1655/04-38

Ron, S.R., Coloma, L.A. \& Cannatella, D.C. (2006) Phylogeny of the túngara frog genus Engystomops (=Physalaemus pustulosus species group; Anura: Leptodactylidae). Molecular Phylogenetic and Evolution, 39, 392-403. https://doi.org/10.1016/j.ympev.2005.11.022

Swofford, D.L. (2002) PAUP*. Phylogenetic analysis using parsimony (*and other methods). Sinauer, USA.

Vaira, M., Akmentins, M., Attademo, M., Baldo, D., Barrasso, D., Barrionuevo, S., Basso, N., Blotto, B., Cairo, S., Cajade, R., Céspedez, J., Corbalán, V., Chilote, P., Duré, M., Falcione, C., Ferraro, D., Gutierrez, F.R., Ingaramo, M.del R., Junges, C., Lajmanovich, R., Lescano, J:N., Marangoni, F., Martinazzo, L., Marti, R., Moreno, L., Natale, G.S., Pérez Iglesias, J.M., Peltzer, P., Quiroga, L., Rosset, S., Sanabria, E., Sánchez, L., Schaefer, E., Úbeda, C. \& Zaracho, V. (2012) Categorización del estado de conservación de los anfibios de la República Argentina. Cuadernos de Herpetología, 26, 131-159.

Vanzolini, P.E. (1953) On the type locality of some Brazilian reptiles and amphibians collected by H H Smith and described by E D Cope. Revista Brasilera de Biologia, 13, 73-74.

https://doi.org/10.2307/1440148

APPENDIX I. Specimens examined.

Physalaemus barrioi.-BRAZIL: SÃO PAULO: Serra da Bocaina, CFBH 227, 17516, 17519, 18120, 21984-88, 22541-2, 24182, 28817, 30815-25, 32191, 33883, 36072.

Physalaemus evangelistai.-BRAZIL: MINAS GERAIS: Ouro Preto, Estrada btween Ouro Branco and Ouro Preto CFBH 24381; Santana do Riacho, Serra do Cipó km 113, CFBH 37739.

Physalaemus gracilis._- BRAZIL: RIO GRANDE DO SUL: Porto Alegre, Morro Teresópolis MACN (Ex-CENAI) 682, 1164; Lag. Viamão MACN 506-8, 1160-2, 1429-30. Torres, MACN 33641-8. URUGUAY: CANELONES: MACN (EXCENAI) 3089-90, 3235-7, 3582; Atlántida, MACN 256, 1163. CERRO LARGO: Road 8 between Treinta y Tres and Melo, MACN 654. MONTEVIDEO: Arroyo Pantanoso, MACN 4433-42; Malvín, MACN 3320, 3353, 3362; Parque Rodó, MACN 3580.

Physalaemus lisei.-BRAZIL: RIO GRANDE DO SUL: Gravataí, near Campus Palabra da Vida, LGE 15666-8.

Physalaemus jordanensis.-BRAZIL: MINAS GERAIS: Poços de Caldas. Morro do Ferro CFBH 32-35; BR 146, between Poços de Caldas and Andradas, CFBH 35887. Campos do Jordão, CFBH 9903, 9915. Conceição dos Ouros, Fazenda Chapada, CFBH 39917. 